Bangladesh J. Bot. 44(2): 267-276, 2015 (June)

\title{
VEGETATION COMPOSITION AND ECOLOGICAL GRADIENTS OF SUBTROPICAL-MOIST TEMPERATE ECOTONAL FORESTS OF NANDIAR KHUWAR CATCHMENT, PAKISTAN
}

\author{
Faizul HaQ*, Habib Ahmad and Zafar IQbal \\ Department of Botany, Hazara University Mansehra, Pakistan \\ Key words: Floristic composition, Ecological gradients, Nandiar Khuwar, Battagram
}

\begin{abstract}
Present study was conducted in the mixed Pinus roxburghii Surgent and Pinus wallichiana A.B. Jackson forests of Nandiar Khuwar catchment Battagram District of Pakistan. The aim of this study was to examine the spatial pattern of vegetation composition and its relationship to microclimatic and edaphic factors. Vegetation sampling was carried out using 12 stands between elevations of 1250 - $2050 \mathrm{~m}$ in the study area. Four plant communities were recognized through TWINSPAN classification. Life form was dominated by nanophanerophytes and leaf size spectra were dominated by microphyll. The maximum similarity index value (32.9) was recorded between $P$. roxburghii, $P$. wallichiana, $Q$. incana community and $Q$. incana, $P$. roxburghii, $P$. wallichiana community. In Bray-Curtis ordination, maximum ordination score $(0.746)$ was recorded for axis 1. In DCA ordination, maximum gradient length (2.43) was recorded for axis 1 with eigenvalue 0.35 . In CCA ordination, maximum eigenvalue was recorded for axis $1(0.35)$. The total variance (inertia) in the species data was 2.15 , explanatory variables account for $100 \%$. On axis 1 the maximum correlation $(-0.749)$ and maximum tau value $(-0.565)$ was recorded for wet bulb. On axis 2 the maximum negative correlation value was recorded for temperature $(-0.553)$ and maximum tau value was recorded for slope aspect $(-0.480)$.
\end{abstract}

\section{Introduction}

Microclimate is a local atmospheric zone where climate differs from surrounding area and it may be small as a few square feet or as large as many square miles (Atri et al. 2007). The contributing factor to microclimate is the slope or aspect of an area. South-facing slopes in the Northern Hemisphere and North facing slopes in the Southern Hemisphere are exposed to more direct sunlight than opposite slopes and are therefore warmer for longer. The altitude, latitude and longitude were responsible for change in microclimate (Ahmed 1988). The altitudinal, latitudinal and longitudinal spatial variation of temperature greatly affects climates and the distribution of biodiversity (Daubenmire 1943). Slope aspect has direct impact on the diversity and species richness (Hoveizeh 1997). Humidity of certain zones varies with altitude and is a significant factor in determining altitudinal Zonation (Malik et al. 2007). The distribution with altitude of every plant species gives an idea of its ecological plasticity (Angelova and Tashev 2005). The altitudinal Zonation in mountainous regions describes the natural layering of ecosystems that occurs at distinct altitudes due to varying environmental conditions. Temperature, humidity, soil composition, and solar radiation are important factors in determining altitudinal zones, which consequently support different vegetation and animal species (Daubenmire 1943, Peter and Rob 1991). A variety of environmental factors determines the boundaries of altitudinal zones found on mountains, ranging from direct effects of temperature and precipitation to indirect characteristics of the mountain itself as well as biological interactions of the species. Zonation produces discrete communities along an elevation gradient (Shipley and Keddy 1987).

*Author for correspondence: < faizulhaq80@yahoo.com> Department of Botany, Hazara University Mansehra, Pakistan. 
Nandiar Khuwar catchment a part of District Battagram is located between $34^{\circ} 33^{\prime}$ and $34^{\circ}$ $47^{\prime}$ north latitude and $72^{\circ} 55^{\prime}$ and $73^{\circ} 14^{\prime}$ east longitude. Nandiar Khuwar catchment ranges in altitude from $525 \mathrm{~m}$ at Thakot to $3817 \mathrm{~m}$ above mean sea level at Malkisar (Haq et al. 2010).

\section{Materials and Methods}

In the mixed Pinus roxburghii Surgent and Pinus wallichiana A.B. Jackson forests of Nandiar Khuwar catchment 12 stands were selected on the basis of physiognomy. Line transect method was used for phytosociological analysis (Buckland et al. 2007). The vegetative characteristics (density, relative density, cover, relative cover, frequency, relative frequency and important value index) of each stand were recorded. Importance value (Brown and Curtis 1952), were used to rank each species and the plant species with the highest importance value in the stand were considered as the dominant species. For multivariate ordination analyses, Canoco 5 version, and PC-ORD 6 were used. For classification of stands and species, TWINSPAN classification was used. In ordination Bray-Curtis ordination, DCA and CCA were used. Life form, leaf size spectra and index of similarity and dissimilarity were recorded for each plant community.

\section{Results and Discussion}

In mixed Pinus roxburghii and $P$. wallichiana forests a total of 130 species were recorded in 12 stands between an elevation of 1250 - 2050m above mean sea level. In this vegetational zone four plant communities were recognized through TWINSPAN classification on cut level 2 (Fig. 1). Nanophanerophytes were dominated with 25 species followed by geophytes contributing 24 species. The leaf size spectra were dominated by microphyll with 58 species followed by mesophyll contributing 42 species. The maximum similarity index value (32.9) was recorded between Pinus, Pinus, Quercus community and Quercus, Pinus, Pinus community. The dissimilarity index was maximum (82.80) between Pinus, Pinus, Quercus community and Pinus, Quercus, Fragaria community.

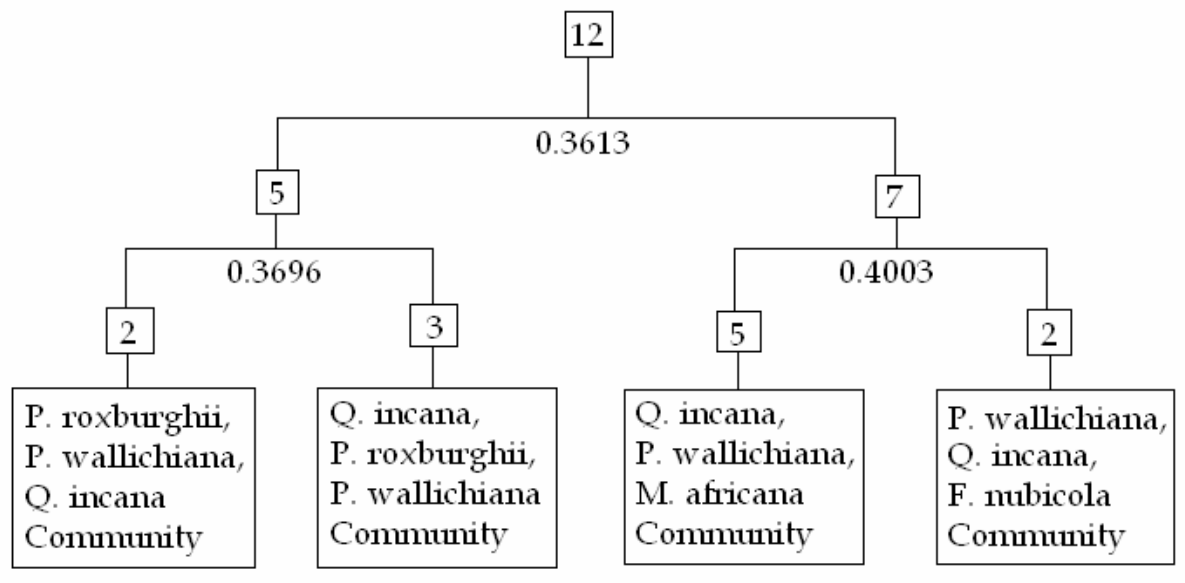

Fig. 1. TWINSPAN classification in mixed $P$. roxburghii and $P$. wallichiana forests.

\section{Pinus, Pinus, Quercus community}

$P$. roxburghii, $P$. wallichiana, $Q$. incana community was recognized in two stands Gada and Belandkot between 1250 and $1650 \mathrm{~m}$ elevations. In this community 83 plant species were 
recorded. The biological spectrum was dominated by nanophanerophytes contributing 20 species (Table 1). The leaf size spectrum was dominated by microphyll contributing 37 species (Table 2).

\section{Quercus, Pinus, Pinus community}

Q. incana, P. roxburghii, $P$. wallichiana community was recognized in three stands Lundai I, Anora II and Anora III between elevations of $1450-1800 \mathrm{~m}$. In this community 72 plant species were recorded. The biological spectrum was dominated by nanophanerophytes with 18 species followed by therophytes with 12 species (Table 1). The leaf size spectrum was dominated by mesophyll and microphyll each contributing 26 plant species (Table 2).

\section{Quercus, Pinus, Myrsine community}

Q. incana, P. wallichiana, M. africana community was recognized in five stands Shabora I, Shabora II, Deshara, Paimal V and Dabrai between elevations of 1250 and $1550 \mathrm{~m}$. In this community 70 plant species were recorded. Biological spectrum was dominated by hemicryptophytes contributing 16 plant species followed by geophytes with 15 plant species (Table 1). Leaf size spectrum was dominated by microphyll contributing 30 species followed by mesophyll with 20 species (Table 2).

\section{Pinus, Quercus, Fragaria community}

P. wallichiana, Q. incana, F. nubicola community was recognized in two stands Lundai II and Sarmast between elevations of 1800 and $2050 \mathrm{~m}$. In this community 42 plant species were recorded. The biological spectrum was dominated by nanophanerophytes contributing 10 species followed by hemicryptophytes with 8 species (Table 1). Leaf size spectrum was dominated by mesophyll with 18 species followed by microphyll contributing 13 species (Table 2).

Table 1. Number of species contributed by life form classes in different plant communities.

\begin{tabular}{|c|c|c|c|c|c|c|c|c|}
\hline & MAP & MEP & MIP & NAP & CHP & $\mathrm{HCP}$ & GEP & THP \\
\hline $\begin{array}{l}\text { P. roxburghii, } P . \text { wallichiana, } \\
\text { Q. incana community }\end{array}$ & 02 & 09 & 09 & 20 & 07 & 08 & 16 & 12 \\
\hline $\begin{array}{l}\text { Q. incana, } P . \text { roxburghii, } \\
\text { P. wallichiana community }\end{array}$ & 02 & 04 & 07 & 18 & 07 & 11 & 11 & 12 \\
\hline $\begin{array}{l}\text { Q. incana, } P \text {. wallichiana, } \\
\text { M. africana community }\end{array}$ & 02 & 03 & 04 & 10 & 07 & 16 & 15 & 13 \\
\hline $\begin{array}{l}\text { P. wallichiana, Q. incana, } \\
\text { F. nubicola community }\end{array}$ & 02 & 03 & 04 & 10 & 02 & 08 & 06 & 07 \\
\hline
\end{tabular}

Table 2. Number of species contributed by leaf size spectra in different plant communities.

\begin{tabular}{lcccccc}
\hline & Macro & Meso & Micro & Nano & Lepto & Aphyllus \\
\hline $\begin{array}{c}\text { P. roxburghii, } P \text {. wallichiana, } \\
\text { Q. incana community }\end{array}$ & 02 & 27 & 37 & 12 & 02 & 03 \\
$\begin{array}{c}\text { Q. incana, } P \text {. roxburghii, } \\
\quad \text { P. wallichiana community }\end{array}$ & 02 & 26 & 26 & 13 & 03 & 02 \\
$\begin{array}{c}\text { Q. incana, } P \text {. wallichiana, } \\
\text { M. africana community }\end{array}$ & 02 & 20 & 30 & 16 & 02 & 00 \\
$\begin{array}{c}P . \text { wallichiana, Q. incana, } \\
\text { F. nubicola community }\end{array}$ & 03 & 18 & 13 & 07 & 01 & 00 \\
\hline
\end{tabular}


Ordination: In Bray-Curtis ordination (ordination of stands in species space) 12 stands and 130 species were analyzed. The ordination scores (Distances) were from Anora II $(0.000)$ to Deshara (0.746) on axes 1 . The regression coefficient for this axis was -4.74 ; variance in distance from the first end point was 0.09 . Axis 1 extracted $18.14 \%$ of original distance matrix. The ordination scores for axis 2 were from Gada (0.000) to Dabrai (0.725). The regression coefficient for this axis was -6.66 ; variance in distance from the first end point was 0.08 . Axis 2 extracted $17.84 \%$ of original distance matrix. The ordination scores for axis 3 were from Belandkot $(0.000)$ to Sarmast (0.658). The regression coefficient for this axis was -5.88 ; variance in distance from the first end point was 0.07 . Axis 3 extracted $13.68 \%$ of original distance matrix (Table 3 ).

Table 3. Bray-Curtis ordination of stands in species space.

\begin{tabular}{|c|c|c|c|c|c|c|}
\hline Statistic & \multicolumn{2}{|c|}{ Axis 1} & \multicolumn{2}{|c|}{ Axis 2} & \multicolumn{2}{|c|}{ Axis 3} \\
\hline \multirow{2}{*}{ Ordination scores } & Anora II & Deshara & Gada & Dabrai & Belandkot & Sarmast \\
\hline & 0.000 & 0.746 & 0.000 & 0.725 & 0.000 & 0.658 \\
\hline Regression coefficient & \multicolumn{2}{|c|}{-4.74} & \multicolumn{2}{|c|}{-6.66} & \multicolumn{2}{|c|}{-5.88} \\
\hline Variance in distance from the first end point & \multicolumn{2}{|c|}{0.09} & \multicolumn{2}{|c|}{0.08} & \multicolumn{2}{|c|}{0.07} \\
\hline Original distance matrix & \multicolumn{2}{|c|}{$18.14 \%$} & \multicolumn{2}{|c|}{$17.84 \%$} & \multicolumn{2}{|c|}{$13.68 \%$} \\
\hline
\end{tabular}

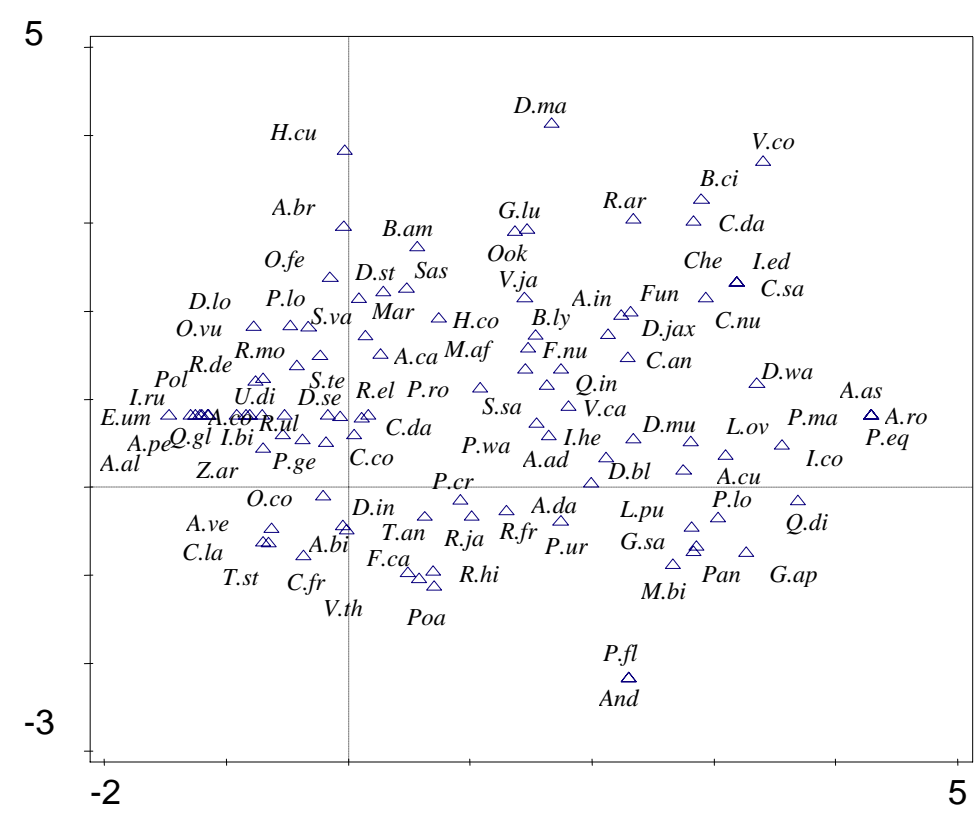

Fig. 2. DCA ordination of the vegetation of study area.

In DCA ordination with supplementary variables the maximum gradient length (2.43) was recorded for axis 1 with eigenvalue 0.35 . The gradient length for axis 2 was 2.07 with eigenvalue 0. 17 (Table 4). In DCA ordination different species clustered in ordination space. Bergenia ciliata, Rhododendron arboretum and Vibernum cotonifolim were more correlated. Similarly Pinus wallichiana, Pinus roxburghii, Indigofera heterantha and Sarcococca saligna clustered near each other (Fig. 2). 
In CCA ordination the maximum Eigenvalue were recorded for axis $1(0.35)$ followed by axis $2(0.30)$ and axis $3(0.25)$. The percentage variance explained for axis 1,2 and 3 were $16.45,30.78$ and 42.52 , respectively. The total variance (inertia) in the species data were 2.15 , explanatory variables account for $100 \%$. Pseudo-canonical correlation for all axis were 1.00 . The permutation test results for all axes were pseudo- $\mathrm{f}<0.1, \mathrm{p}=1$ (Table 5).

Table 4. DCA ordination on different axis.

\begin{tabular}{lllll}
\hline Statistic & 1 & \multicolumn{1}{c}{3} & \multicolumn{1}{c}{4} \\
\hline Eigenvalues & 0.35 & 0.17 & 0.07 & 0.02 \\
Explained variation (cumulative) & 16.45 & 24.56 & 27.72 & 29.04 \\
Gradient length & 2.43 & 2.07 & 1.66 & 1.57 \\
\hline
\end{tabular}

Table 5. CCA ordination on different axis.

\begin{tabular}{lllll}
\hline Statistic & 1 & 2 & 3 & 4 \\
\hline Eigenvalues & 0.35 & 0.30 & 0.25 & 0.23 \\
Explained variation (cumulative) & 16.45 & 30.78 & 42.53 & 53.53 \\
Pseudo-canonical correlation & 1.00 & 1.00 & 1.00 & 1.00 \\
Permutation test results on all axes & Pseudo- $\mathrm{f}<0.1, \mathrm{p}=1$ & & \\
Total variation is 2.15, explanatory variables account for $100 \%$ & & \\
\hline
\end{tabular}

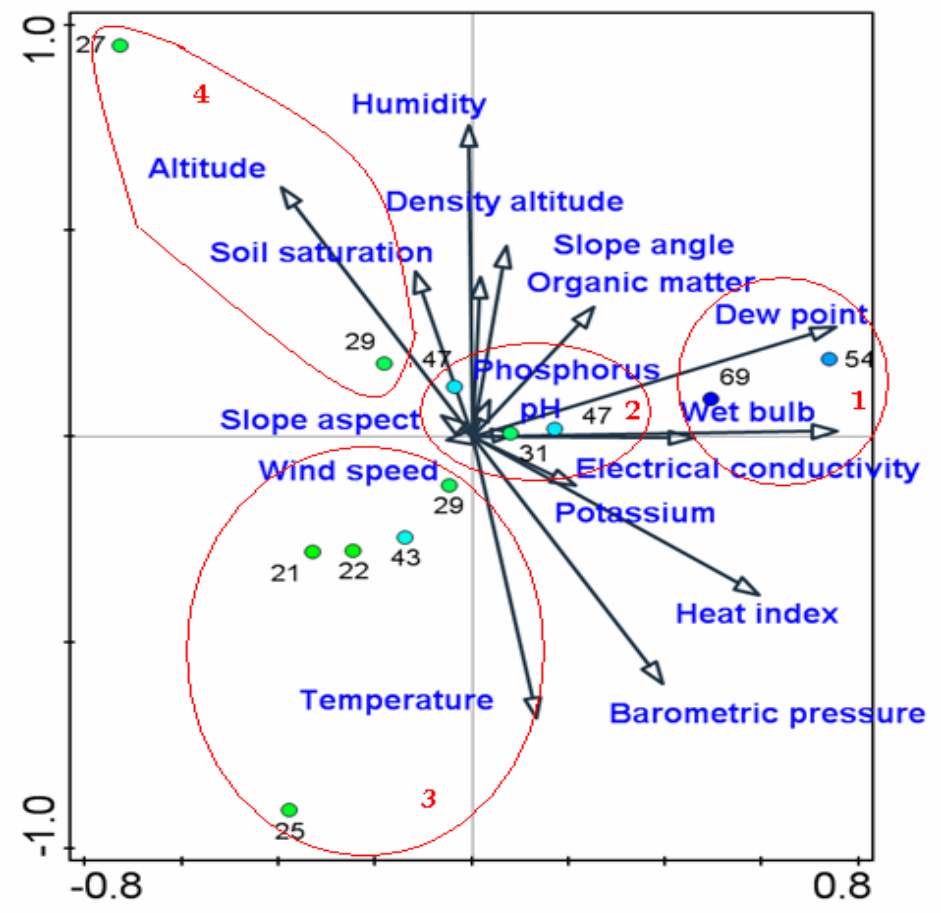

Fig. 3. CCA ordination of sands of study area. 
In CCA ordination the maximum strength were recorded for the environmental variables temperature, barometric pressure, heat index, wet bulb, dew point, humidity and altitude. The average values of the environmental variables were recorded for wind speed, slope aspect, phosphorus and $\mathrm{pH}$. The intermediate strengths were recorded for soil saturation, slope angle, density altitude, soil organic matter, electrical conductivity and potassium. The species of $P$. roxburghii, $P$. wallichiana, $Q$. incana community were positively correlated with dew point, wet bulb and electrical conductivity. The species of different stands of $Q$. incana, $P$. roxburghii, $P$. wallichiana community clustered at almost average position. The species of different stands of $Q$. incana, $P$. wallichiana, $M$. africana community were negatively correlated with most of the environmental variables. The species of different stands of $P$. wallichiana, $Q$. incana, F. nubicola community clustered at high altitude, soil saturation and atmospheric humidity (Figs 3, 4).

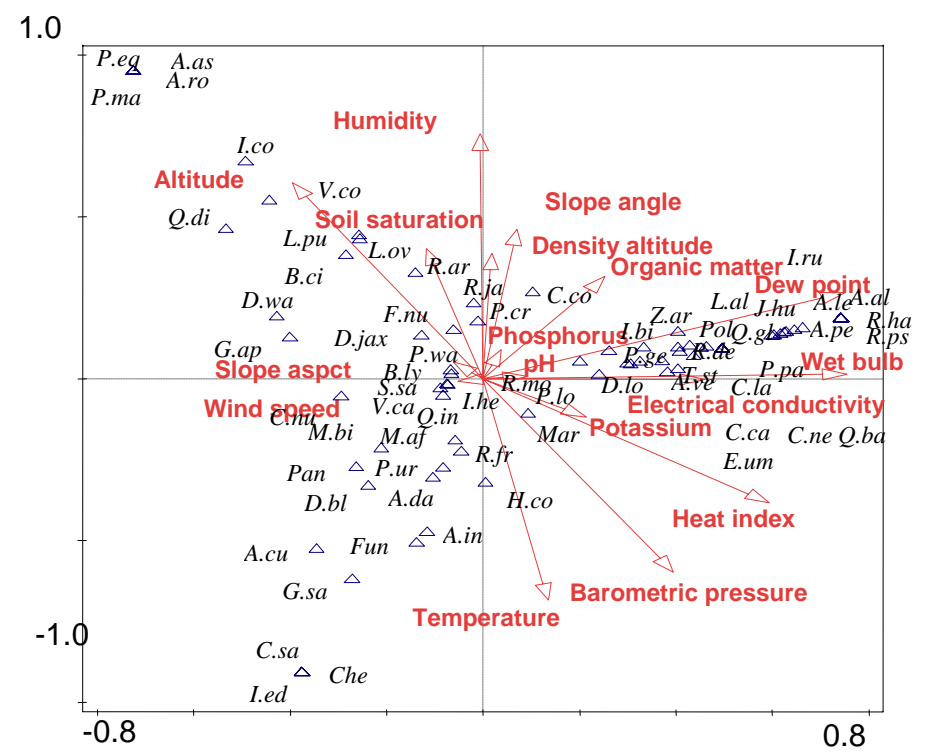

Fig. 4. CCA ordination of species of study area.

The environmental variables behave differently on different axes. On axis 1 the maximum correlation value were recorded for wet bulb $(-0.749)$ followed by heat index $(-0.645)$, dew point $(-0.639)$, altitude $(0.429)$ and barometric pressure $(0.425)$. The minimum correlation value was contributed by slope aspect (0.075). On axis 1 maximum tau value was recorded for wet bulb $(-0.565)$ while minimum tau value was recorded for wind speed $(0.000)$. On axis 2 the maximum correlation value was recorded for temperature $(-0.553)$ while minimum correlation value was recorded for electrical conductivity (0.033). On axis 2 the maximum tau value was recorded for slope aspect $(-0.480)$ while minimum tau value $(0.015)$ was recorded for $\mathrm{pH}$ (Figs 5-10).

The dominance diversity curves showed that the $Q$. incana, $P$. wallichiana, $P$. roxburghii, $I$. heterantha, S. saligna and B. lyceum were the most frequent species. However, the less frequent species were Hypericum oblongifolium, Debregessia salcifolia, Duhaldea cappa, Cuscuta gigantea and Caropteris grata. The 10 dominant species are shown in Table 6. 
Phytosociology is concerned with plant communities, their relationships, structure, composition, distribution, development and the temporary processes modifying them. Phytosociological surveys helps in planning, management and exploitation of natural resources (Mashwani et al. 2011). In mixed P. roxburghii and P. wallichiana forests a total of 130 species were recorded from 12 stands between elevations of 1250 and $2050 \mathrm{~m}$ above mean sea level. In this vegetational zone four plant communities were recognized through TWINSPAN classification (Fig. 1). The dominance diversity curves showed that the Q. incana, P. wallichiana, P. roxburghii, I. heterantha, S. saligna and B. lyceum were the most frequent species (Table 6).

Table 6. Dominance diversity curves showing the 10 most abundant species.

\begin{tabular}{llllllllll}
\hline Species & R. Abu & Log & Sum & R. Freq & Freq & Mean & S. Dev. & CV\% & V/M \\
\hline Quercus incana & 1 & 2.01 & 103.98 & 1 & 12 & 8.66 & 4.66 & 53.84 & 2.51 \\
Pinus wallichiana & 2 & 2.00 & 100.93 & 2 & 12 & 8.41 & 4.44 & 52.84 & 2.34 \\
Pinus roxburghii & 3 & 1.83 & 68.05 & 6 & 12 & 3.88 & 1.41 & 67.10 & 2.55 \\
Indigofera heterantha & 4 & 1.66 & 46.56 & 3 & 12 & 3.88 & 1.41 & 36.58 & 0.51 \\
Sarcoccoca saligna & 5 & 1.62 & 41.71 & 4 & 12 & 3.47 & 1.40 & 40.30 & 0.56 \\
Myrsine africana & 6 & 1.59 & 39.63 & 10 & 9 & 3.30 & 3.19 & 96.65 & 3.08 \\
Berberis lyceum & 7 & 1.54 & 34.85 & 7 & 12 & 2.90 & 1.46 & 50.44 & 0.73 \\
Themeda anathera & 8 & 1.50 & 32.22 & 13 & 8 & 2.68 & 2.92 & 108.94 & 3.18 \\
Fragaria nubicola & 9 & 1.48 & 30.36 & 9 & 9 & 2.53 & 1.99 & 78.84 & 1.57 \\
Rubus fructicosus & 10 & 1.47 & 29.57 & 14 & 8 & 2.46 & 2.51 & 101.93 & 2.56 \\
\hline
\end{tabular}

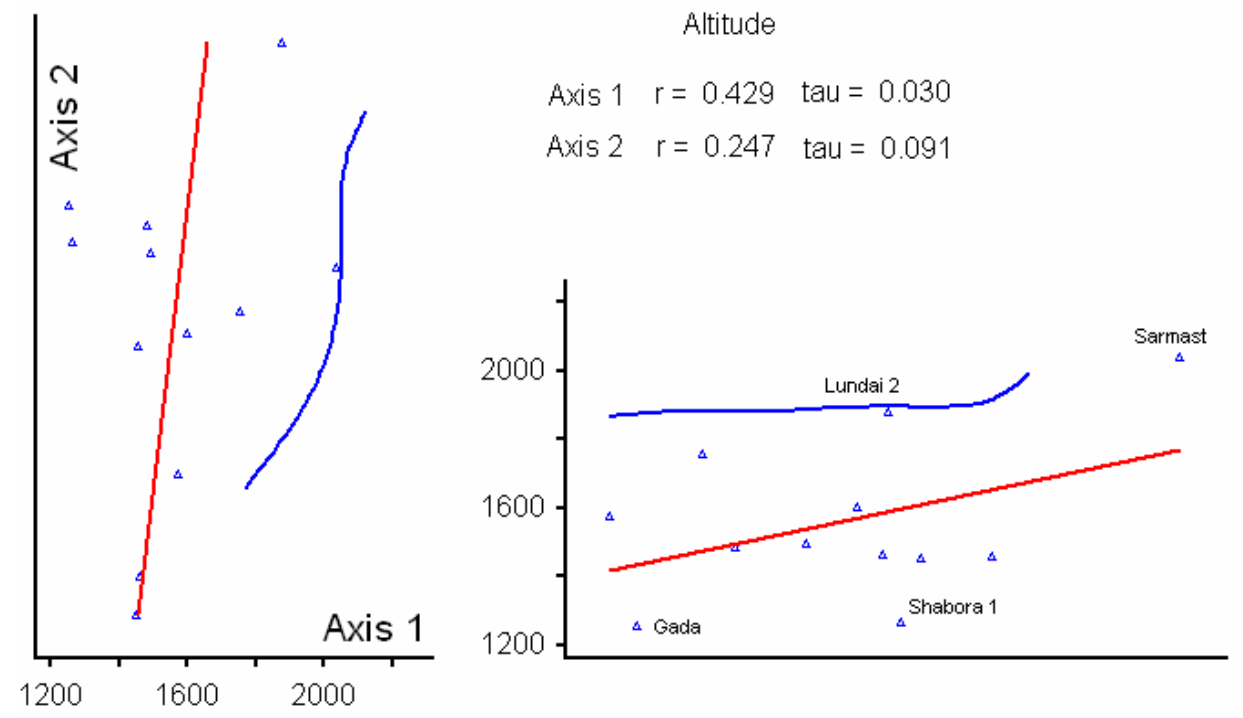

Fig. 5. Correlation and regression coefficient of altitude on different axis.

In this vegetation zone life form was dominated by nanophanerophytes with 25 species followed by geophytes contributing 24 species. The dominance of nanophanerophytes indicates that the vegetation of the study area was disturbed due to over grazing, loss of habitat and 
anthropogenic effects (Meher-Homji 1981). The leaf size spectra were dominated by microphyll with 58 species followed by mesophyll contributing 42 species. The leaf size spectra showed that the study area receive a good amount of precipitation (Mashwani et al. 2011). The maximum index of similarity (32.9) was recorded between P. roxburghii, P. wallichiana, Q. incana community and $Q$. incana, $P$. roxburghii, $P$. wallichiana community. The index of dissimilarity was maximum $(82.80)$ between $P$. roxburghii, $P$. wallichiana, $Q$. incana community and $P$. wallichiana, Q. incana, F. nubicola community (Angelova and Tashev 2005).

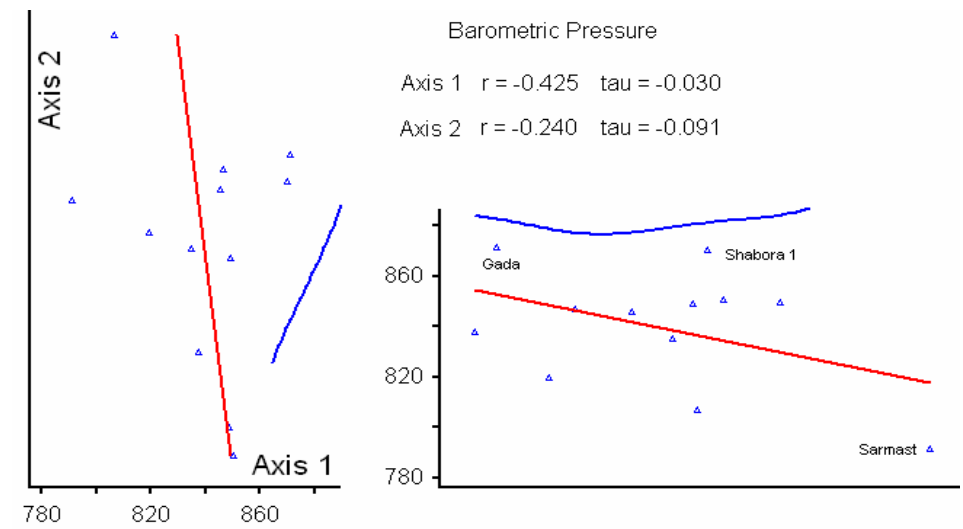

Fig. 6. Correlation and regression coefficient of barometric pressure on different axis.

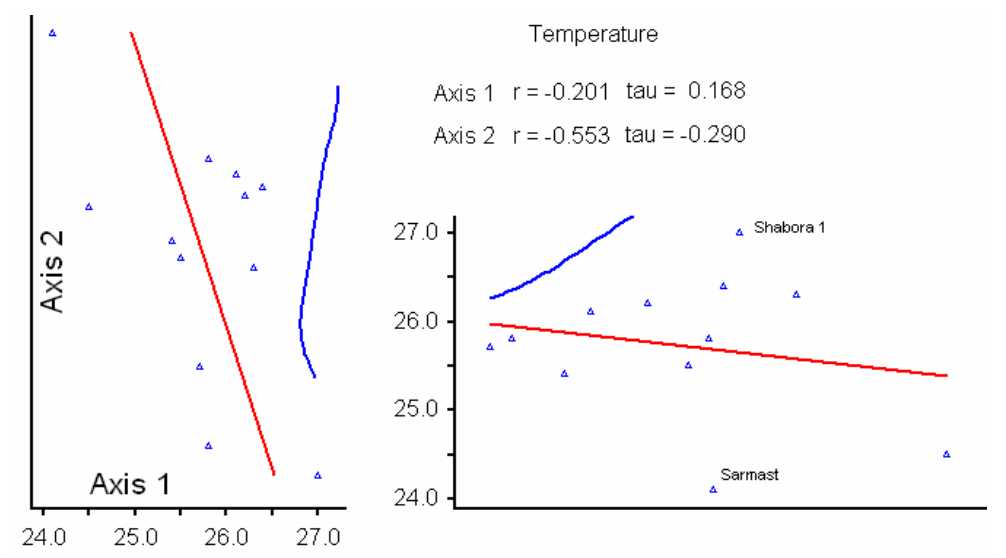

Fig.7. Correlation and regression coefficient of temperature on different axis.

The response data are compositional and have a gradient 2.4 SD units long. The total variance (inertia) in the species data were 2.15 , explanatory variables account for $100 \%$. In Bray-Curtis ordination the ordination scores (Distances) were maximum (0.746) for axis 1 (Table 3). In DCA ordination the maximum gradient length (2.43) were recorded for axis 1 with eigenvalue 0.35 (Table 4). In CCA ordination the maximum eigenvalue (0.35) was recorded for axis 1 (Table 5).

The environmental variables behave differently on different axes. On axis 1 the maximum correlation $(-0.749)$ and tau value $(-0.565)$ were recorded for wet bulb (Fig.10). On axis 2 the maximum negative correlation value was recorded for temperature $(-0.553)$ and maximum tau value $(-0.480)$ was recorded for slope aspect (Fig. 7). 

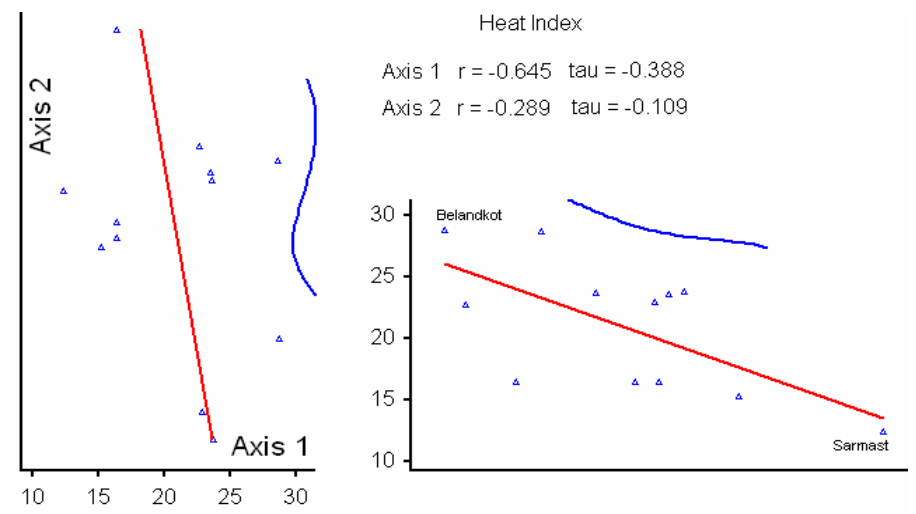

Fig. 8. Correlation and regression coefficient of heat index on different axes.

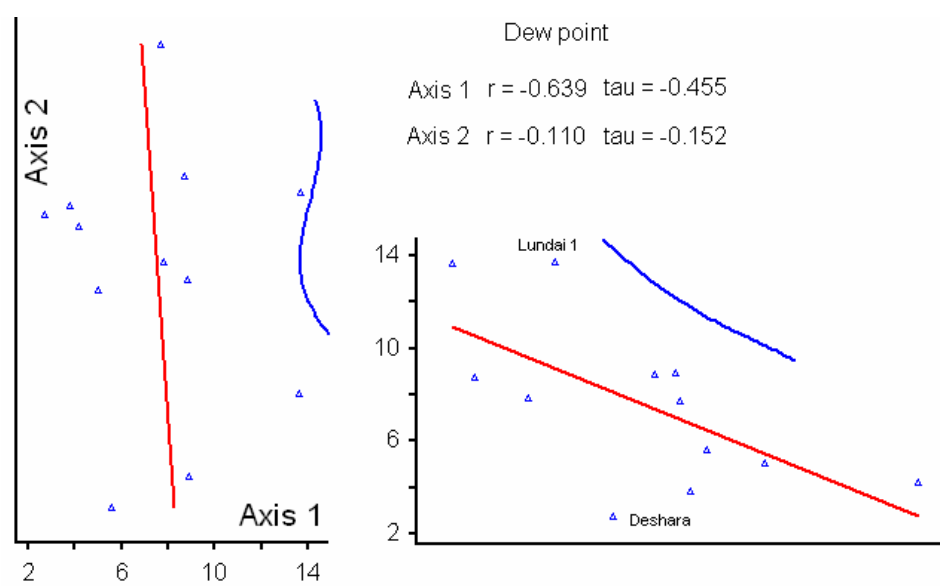

Fig. 9. Correlation and regression coefficient of dew point on different axes.
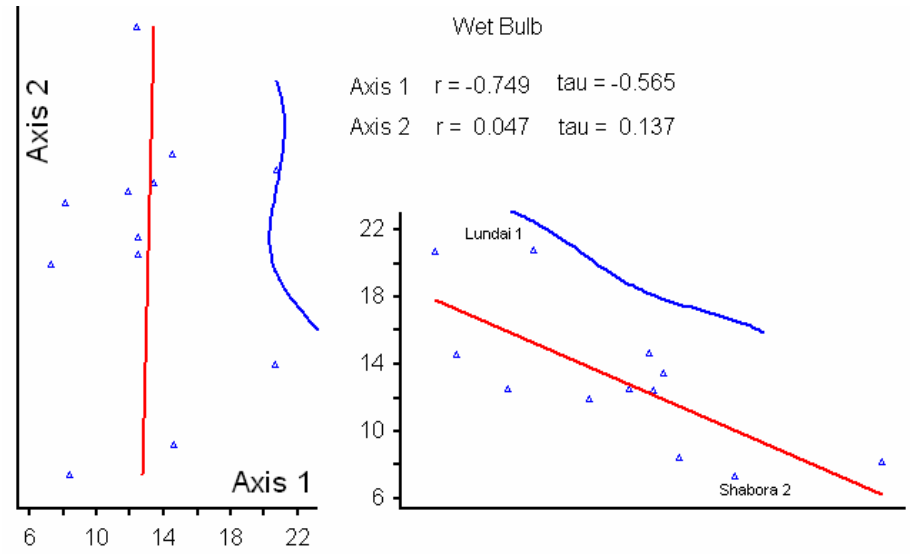

Fig. 10. Correlation and regression coefficient of wet bulb on different axes. 


\section{References}

Ahmed M 1988. Plant communities of some northern temperate forests of Pakistan. Pak. J. For. 38: 33-40.

Angelova K and A Tashev 2005. Complex analysis of the life forms of flowering plants in Mount Chepan and their vertical ranges of spread in altitude. Trakia J. Sci. 3(6): 32-35.

Atri M, S M Shahgolzari and A Yavari 2007. Effective ecological factors in the distribution and diversity of Astragalus verus and Astragalus glaucops in West of Iran.

Brown RJ and JJ Curtis 1952. The upland conifer-hardwood communities of southern Wisconsin. Ecol. Manog. 22: 217-234.

Buckland ST, DL Borchers, A Johnston, PA Henrys and TA Marques 2007. Line Transect Methods for Plant Surveys. Biometrics 63(4): 989-998.

Daubenmire RF 1943. "Vegetational Zonation in the Rocky Mountains". Botanical Review 9(6): 325-393.

Haq F, H Ahmad, M Alam, I Ahmad and R Ullah 2010. Species diversity of vascular plants of Nandiar valley western Himalaya, Pakistan. Pak. J. Bot. Special Issue (S.I. Ali Festschrift) 42: 213-229.

Hoveizeh H 1997. Study of the vegetation cover and ecological characteristics in saline habitat of Hoor-eShagegan. J. Res. and Const. 34(1): 27-31.

Malik NZ, M Arshad and SN Mirza 2007. Phytosociological Attributes of different plant Communities of Pir Chinasi Hills of Azad Jammu and Kashmir. Inter. J. Agri. Biol. 09(4): 569-574.

Mashwani ZR, M Arshad, M Ahmad and MA Khan 2011. Diversity and distribution pattern of alpine vegetation along Lake Saif-ul-Mulook, Western Himalaya, Pakistan. International Conference on Environmental, Biomedical and Biotechnology IPCBEE vol.16 (2011) (C) (2011) IACSIT Press, Singapoore 155-163.

Meher-Homji VM 1981. Envirnomental implication of life form spectra from India. J. Econ. Taxo. Bot. 2: 23-30.

Peter FJ and GS Rob 1991. An altitudinal zonation of tropical rain forests using byrophytes. J. Biogeo. 18(6): 669-678.

Shipley B and PA Keddy 1987. The individualistic and community-unit concepts as falsifiable hypotheses. Vegetation 69: 47-55.

(Manuscript received on 23 December, 2014; revised on 2 March, 2015) 